\title{
ВІЗУАЛІЗАЦІЯ МОДЕЛЮВАННЯ ГІПЕРПРОСТОРОВО-РОЗПОДІЛЕНИХ ГНУЧКИХ КОМП'ЮТЕРНО-ІНТЕГРОВАНИХ ВИРОБНИЧИХ СИСТЕМ
}

\begin{abstract}
Вступ
Інтеграція матеріальних, енергетичних та інформаційних потоків, якими супроводжується функціонування сучасних виробничих систем (BC) з багато-номенклатурністю оброблювальних виробів, дозволяє розглядати таки системи як складні, ієрархічні, диналічні, паралельні, конвеєрні та циклічні [11]. Іншою характерною ознакою ВС є інтеграція та узгодження різноланітних ї̈ складових: необхідного і достатнього за своїм технологічним призначенням для визначеної номенклатури виробів основного устаткування; засобів сервісного обслуговування промислових роботів і упорядкування середовища під групову технологію; матеріальних та інформаційних потоків і засобів їх накопичення, перевантаження, розподілення по обробляючих ресурсах; підсистем автоматизованого проектування керуючих програм, технологічного оснащення і типових технологічних процесів виготовлення виробів певної номенклатури $[3,23,28]$. В такому випадку можна говорити про ВС як про гнучкі комп'ютерно-інтегровані (ГКIBC), оскільки різноманітні матеріальні/енергетичні/інформаційні потоки, відмінне за класом та призначенням устаткування, а також основні складові підсистеми підготовки, проектування, управління і технологічна функціонують, а диспетчеризація потоків реалізується за допомогою засобів комп'ютерної підтримки і забезпечення організаційної, структурної, технологічної та за потужністю гнучкості [31], яка у цілому проявляеться у спроможності шляхом параметричних і структурних змін, що не виходять за межі вихідного означення даної системи, реагувати на ініційовані зовні зміни поточного завдання або умов (середовища) його виконання при додержані прийнятих обмежень на часові та інші параметри [6].

Нарешті, ГКІВС може розглядатися як логістична систела (ЛС). Типова логістична система складається з потоків товарів (вантажів) та послуг, спостереження (вивчення) і керування (регулювання) цілими потоками [22, 34,]. Адже серед складових процесів ГКIBC найбільш поширеними є транспортування, розподілення і власне виготовлення виробів. Конфрігурація цих процесів і складових і є головним об“єктом керування ЛС. Іншими словами, мета полягає в досягненні добре синхронізованого режиму динамічної взаємодії компонент системи. Серед багатьох якісних

(c) О.І. Лісовиченко, Б.М. Данішевський, Є.С. Пуховський, Ю.М. Ланкін, Л.С. Ямпольський, 2004
\end{abstract}


показників ( таких, як „вузькі місця” та простоювання), які визначають режим функціонування ГКІВС, блокування (тупикові ситуації) процесу з причин наявності „критичного циклу” в послідовності дії [32], а також ймовірності виникнення нештатних режимів роботи через вплив на систему надзвичайних фракторів $[18,27]$ відіграють чи не найсуттевішу роль [16].

У будь-якому випадку ГКІВС взагалі, а складальні системи, зокрема, в розв'язанні задач синтезу/аналізу розглядається, як правило, як віртуально створені дискретно-подійні систели (ДПС), зміна станів яких здійснюеться в дискретні, непередбачені моменти часу при здійснені подій [20].

Отже реалізація та дослідження ГКІВС ускладнюеться гетерогенною ïx природою (інтегруванням різних за фрізичною природою і виконуючих функцій складових компонент) і випливаючими з притаманних для таких систем з вищеозначеними властивостями (динамічність, конвеерність, циклічність, тощо) особливостями синхронізації та координації [33]. Звичайно уживані при цьому методи розв'язання синтезу/аналізу (верифікації, ідентифікації, моделювання та проектування) процесів в таких системах спеціалізовані i, по-перше, не підтримують автоматизації послідовності “синтез - імітація - верифікація" в межах однорідного семантичного середовища (засоби теорії масового обслуговування, імітаційного моделювання, теорій графів і сіток, в тому числі апарата сіток Петрі та його поширень) [21], а по-друге, не передбачають, як правило, паралельної візуалізації проходження подій в системі, і цей аспект надзвичайно впливае на можливість адекватного реагування користувачадослідника в разі створення в системі непередбачених ситуацій [7].

\section{Концептуальний підхід до розв'язання обмежень дослідження ГКІВС}

Шлях до розв'язання першого обмеження методів дослідження ГКІВС запропонований в роботах $[6,7,20,21]$, де впроваджуеться новий концептуальний підхід, який полягає у створені інтегрованого гіперпросторового селантично-узгодженого середовища лоделювання (ГПСУСМ) систем подібного класу із залученням до середовища ефективних взаємоузгоджених семантичних засобів $[11,21]$ для відбиття логіки (а) диспетчерування і динаміки ситуаційного моделювання транспортних та інорормаційних потоків в оброблювальних ресурсах ГКІВС (ця планарна колпозиційність процесів обумовлюе розподіленість у просторовоподійному моделюванні $[20,29])$ на різних рівнях абстрагування (б) з метою уточнення динамічних властивостей та показників ефективності в заданих обмеженнями умовах (ця міжрівнева трансформація ієрархіиної колпозиційності процесів обумовлюе просторово-ієрархічну розподіленість в моделюванні $[20,30])$ при одночасному урахуванні (в) впливу зовнішніх збурень і внутрішньо-системних критичних факторів, які носять імовірнісній характер і відбивають можливість утворення нових агрегатних (в тому числі, нештатних, тобто непередбачених заздале- 
гідь) станів системи (ця агрегатована колпозиційність станів обумовлюе просторово-агрегатну розподіленість в моделюванні $[4,6,16]) .3$ метою практичного наповнення загальних принципів побудови ГПСУСМ запропоновані численні інструментальні семантичні засоби, які в значній мірі сприяли впровадженню ідеї використання ГПСУСМ для розв'язання прикладних задач моделювання процесів в ГСІВС, а саме: модифрікації апарату сіток Петрі [15] (в тому числі, нечіткі [29] та часові [5] СП), механізм нечіткого мета-управління в складних системах $[6,21]$, методи „віртуальних асинхронних світлофорів” [19] та специфікацій і призначень $[6,14,16]$ для часо-самосинхронізуючого впливу на матеріальні потоки при їх диспетчеруванні з усталеними циклічними станами, правила пріоритетного розподілення з вихідним призначенням при логістичному моделюванні в умовах обмеженої перепускної спроможності обробляючих ресурсів [22], поширення апарату процесних діод- та макс - алгебр $[13,19,24]$ для дослідження динамічної поведінки ГКIВС з часовим навантаженням (формальний апарат для опису властивостей ГКIВC має забезпечувати розвинені набори операцій композиції, компактне синтаксичне подання розрізнених та поєднаних системою компонентів [8], механізми формалізованого подання процесів обробки надзвичайних ситуацій з використанням нейро-фаззі технологій при управлінні процесами в ГКIBC з агрегатними станами [9, 10, 11, 18].

Що стосуеться другого обмеження існуючих підходів до розв'язання задач аналізу/синтезу складних систем, то воно, скоріше, пов'язане з бажаністю оснащення дослідника/проектувальника (надалі - користувача ) засобами анімаційного відтворення в режимі on-line перехідних процесів, якими супроводжуються події в ГКIВС. Перш за все, це стосується проблеми, яка виникає на етапах проектування та переналагоджування ГКІВС, коли йдеться про вимогу максимального використання ресурсів системи, бо недовикористання виробничих потужностей може призводити до зростання виробничого циклу, більш високих витрат на устаткування при проектуванні системи $\mathrm{i}$, як наслідок, до зниження економічних показників виробництва. В свою чергу, ефективність використання устаткування визначається, головним чином, кількістю часу, необхідного для виконання тіеї чи іншої операції, при обмеженнях на енерговитрати, рівень надійності, термін працездатності, тощо. Інакше кажучи, ця проблема значною мірою пов'язана з ієрархічною композиційністю в просторово-іерархічній розподіленості в моделюванні.

Найчастіше проблема деформуеться в задачу часового перевантаження модельних компонент ГКІВС верхнього рівня подання за рахунок уточнення їх часів спрацювання на нижчих рівнях подання. Методологічно задача зводиться до впровадження механізмів пошуку найменшого часу виконання визначеного руху (і далі - сукупності рухів) окремого устаткування (і далі - сукупності устаткувань) у складі ГКІВС, при моделюванні якої використовуеться спеціально запропонований апарат іерархічних самонавантажуючих сіток Петрі (ICHCП) [11, 23, 35]. Верхній рівень ієрархії ІСНСП - моделі як дискретно-подійного відображення процесів в 
ГКІВС уявляе собою часову сітку Петрі (ЧСП) [5] таку, де кожному переходові $j$ ставиться у відповідність визначений інтервал часу $\tau_{j}$, який дорівнюе тривалості його реалізації, тобто тривалості співставленої з ним операції. Нижні рівні моделі призначені для визначення часів спрацювання переходів $\tau_{j}$, чим забезпечують так зване „навантаження” моделі часовими параметрами. Слід зазначити, що нижні рівні іерархії ГКIBC можуть мати іншу семантику, використовувати інші формальні підходи для подання динамічних процесів, відповідних до переходів вищерівневої моделі на сітках Петрі. Для забезпечення автоматизації процесу навантаження переходів ЧСП використовуються певні інтелектуалізованої структури, спроможні аналізувати об'єкт моделювання, використовуючи відповідну семантику на необхідному рівні абстрагування моделі. Алгоритмічно такі структури можна реалізувати за допомогою застосування пошукових модулів [29].

Недоліком всіх розглянутих підходів щодо моделювання процесів ГКІВС е відсутність для користувача синхронізованої візуалізації спостережень за подіями в системі через анімаційне подання аспектів функціонування об'єкта досліджень і графічне відображення кількісно-якісних характеристик процесу при цьому.

\section{Обгрунтування вибору об'екта досліджень}

3 усього спектра устаткування, яке входить до складу ГКІВС, одними з найбільш кінематично-розподіленими у просторі і динамічноскладними через інерційні фрактори і обмеження щодо жорсткіснопружніх властивостей є промислові роботи (ПР), які можуть виконувати на виробництві основні (безпосередньо реалізовувати складні технологічні операції, а саме: складання методами зварювання, згвинчування, точного з'еднування тощо, фррезерування, фарбування і т.д.) та допоміжні (пересування, транспортування, орієнтування, завантаження/розвантаження тощо) операції. Отже, запропоновані інструментальні засоби і підходи щодо до досліджень подібного роду об'єктів в разі отримання достовірних і надійних результатів легко можуть бути адаптовані до будь-якого іншого компоненту ГКIВС. Крім того, є ще один аспект, який надає пріоритетність вибору ПР як об'екта досліджень, який полягає в наступному: оптимізація технологічних процесів обробки/складання, визначених технологічними вимогами їх режимів, практично не залишає резерву для інтенсифрікації останніх, тоді як допоміжні операції, що виконуються ПР і займають суттеву долю технологічного циклу, можуть значно прискорюватись за результатами дослідження динаміки їх реалізації.

\section{Аналіз проблеми планування та візуалізації рухів маніпуляційної системи ПР}

Планування рухів (прийняття рішень про хід дії перед її виконанням) для вирішення обумовленої технологічним процесом задачі з наступним відпрацюванням виконавчими механізмами і контролем виконання ке- 
руючих команд, які необхідні для реалізації цих дій, е однією з головних проблем робототехніки. Система планування дій повинна мати опис підлягаючих маніпулюванню об'єктів, робочого простору і схеми послідовності виконання роботом задачі, початкового і бажаного кінцевого (цільового) стану і виконуеться, як правило, в три етапи: деталізації задачі, моделювання і синтезу робочих програм рухів ПР. При цьому останні два етапи складаються з розв'язання задач кінематики (прямої - управління, або аналізу; оберненої - про положення маніпулятора, або синтезу) і динаміки (відповідно, прямої задачі динамічного аналізу маніпуляційної системи (МС) ПР з плануванням оптимальної траєкторії руху за векторами швидкості або сили, а також оберненої задачі динамічного синтезу з перевіркою можливостей використання даної МС ПР в умовах забезпечення необхідних прискорень і узагальнених сил моментів). Як математичні при реалізації цих етапів найчастіше використовуються аналітичні та Т-матричні $(4 \times 4)$ моделі $[1,2,17]$.

Метою даної роботи було створення автоматизованого робочого місця користувача (AРM) для розв'язання задач синтезу/аналізу МС ПР з плануванням дій останньої при динамічному обслуговуванні технологічних процесів ГКІВС з визначенням та візуалізацією змінних просторових положень ланок МС ПР, підготовки вихідних даних для обладнання дистанційного керування з використанням різноманітних технологічних операцій в довільному робочому просторі.

Прийнятним шляхом для розв'язання означеної задачі могло б стати використання вже розроблених спеціалізованих симуляторів (зокрема, Sim Station, Robot Simulation, RobCad тощо), які значною мірою відрізняються від традиційних систем автоматизованого проектування (CADсистем) засобів тим, що вони дозволяють досліджувати геометрію, кінематику, динаміку рухів. Проте, складнощі системного характеру ( високі вимоги до програмно-дискретної платорорми), сумісності (пов'язані із проблемами обміну результатами роботи з іншими системами), фінансові (вартість повнофункціональних комерційних версій подібних пакетів) обмежують виправдане застосування таких систем у складі АРМ користувача. 3 іншого боку, виконання нової розробки необхідного програмного забезпечення (наприклад, на базі інтегрування CAD- систем і мов високого рівня (C++, Pascal)) потребуе значних часових і матеріальних витрат. Один з таких підходів розв'язання проблеми запропонований в роботах $[25,26]$.

\section{Засоби реалізації АРМ користувача}

Розроблена система визначення/проектування стану та візуалізації як кінцевого, так і проміжних станів МС ПР, описуе його положення по відношенню до заданої абсолютної системи координат, не розглядаючи сили та моменти, що породжують цей рух. Просторове положення захватного пристрою маніпулятора визначається кутовим та поступальним рухом ланок маніпулятора. Опис розташування цих ланок в абсолютній системі відліку може бути виконаний на базі, як зазначалось вище, аналіти- 
чних та Т-матричних моделей. Для визначення взаємного просторового положення двох суміжних ланок використовуеться однорідна матриця перетворення $4 \times 4$, яка складається з чотирьох підматриць (рис. 1 ).

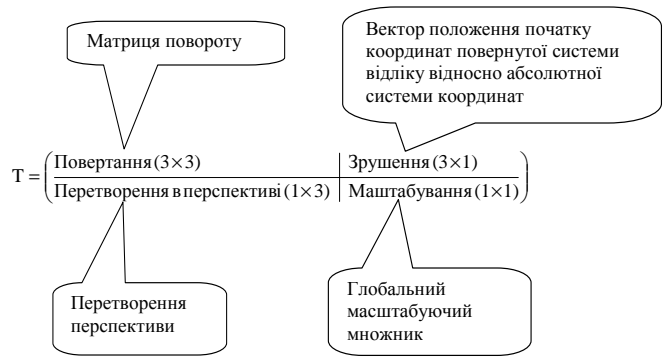

Рис. 1 - Т-матрична модель опису розташування ланок МС ПР.

Процес візуалізації (на основі проведених розрахунків) виконуються ресурсами відеоадаптера, використовуючи графрічні бібліотеки DirectX та OpenGL [12]. Цим самим забезпечуеться паралельність виконання задачі візуалізації: розрахунки (однорідні матриці елементарних поворотів, елементарного зрушення та повороту навколо довільної осі, фрункції від часу динамічного навантаження МC) - через процесор, а візуалізація (створення зображення МС ПР, перехід до дротово-каркасної (рис. 2, б), фотореалістичної моделі (рис. 2 , а), вибір точки спостереження, визначення робочої зони (рис. 2 , в), відтворення перехідного процесу МС (рис.3, а), його графічного зображення (рис.3, б) ) - через відеоадаптер.

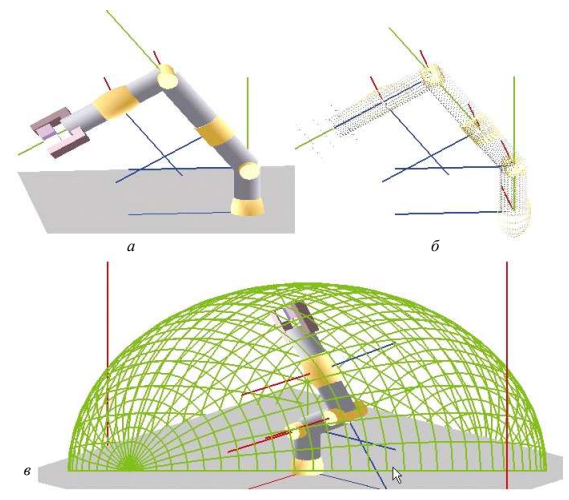

Рис. 2 - Візуалізація МС у вигляді фотореалістичної моделі (а), дротовокаркасної моделі (б), визначення робочої зони МС (в)

Всі розрахунки проводяться на підставі повної інформації (сукупна інформація всіх ланок) про МС, що формуеться. Для візуалізації прямої/оберненої задачі кінематики - це координати, $\mathrm{max} / \mathrm{min}$ значення пере- 


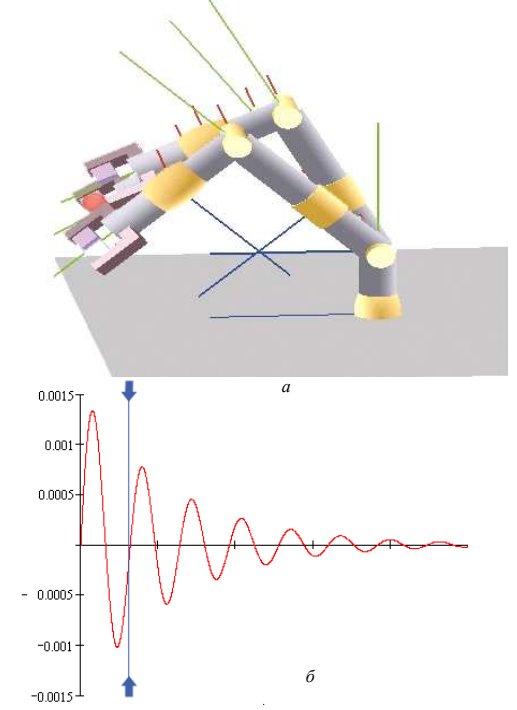

Рис. 3 - Відтворення перехідного процесу при динамічному навантаженні МC (а), графік перехідного процесу (б).

міщень, діаметр ланки (функції біліотеки GLU та DGLUT). Для візуалізації динамічних навантажень ще додається інформація про швидкість позиціювання, необхідна точність позиціювання, коефіціент демпфування кінематичної схеми $\mathrm{MC}$, жорсткість кінематичної схеми MC та маса рухомих ланок.

Алгоритм побудови окремих вузлів і ланок можна окреслити наступними ітераціями:

1. При побудові чергової ланки, її параметри зберігаються в масиві;

2. Перераховуеться матриця положення - координати ланки;

3. Для відображення ланки викликається функція Renderer (яка, в свою чергу, використовуе функції gluCylinder - малювання циліндра, gluSphere - малювання сорери з бібліотек GLU та OpenGL;

4. Для обертання на необхідний кут як окремої ланки, так і $\mathrm{MC}$ в цілому використовуеться функція glRotatef та glTranslatef для переносу на необхідну відстань центра системи координат та інші.

Створене таким чином програмне забезпечення може бути використано для:

візуалізації МС ПР і окремих його ланок;

вирішення як прямої так і оберненої задач кінематики;

візуалізації динамічних навантажень МС ПР і характеристик окремих ланок (у вигляді анімації та графіку перехідних процесів);

динамічного (в процесі виконання сценарію) редагування параметрів як самої МC, так параметрів усіх його ланок і вузлів (колір, максималь- 
на/мінімальна довжина, тип вузла, ширина/висота/довжина і т.д.).

виконання послідовності команд (створення, переміщення, вибір точки спостереження) заздалегідь сорормованого користувачем спеціального сценарію.

\section{Література}

1. Бурдаков С.Ф., Дьяченко В.А., Тимофеев А.Н. Проектирование манипуляторов промышленных роботов и роботизированных комплексов. - М.: Высш. шк.- 1986. - 264 с.

2. Вукобратович М., Стокич Д., Кирчански Н. Неадаптивное и адаптивное управление манипуляционными роботами: Пер. с англ. М.: Мир.- 1989. - 376 с.

3. Гибкие автоматизированные производственные системы / Л.С. Ямпольский, О.М. Калин, М.М. Ткач и др.; Под ред. Л. С. Ямпольского.- К. : Тэхника.- 1985.- 280 с.

4. Гиперпространственная семантика процессов в сложных агрегатированных системах / о.и. Лисовиченко, л.с. Ямпольский, д.и. Герги, к.б. Остапченко, м.м. Ткач//труды фрилиала мгту им. Н.э. Баумана в г. Калуге. Специальный выпуск: материалы международн. Науч.техн. Конф. “приборостроение-2000”, п. Симеиз, 18-23 сентября 2000 г.- c. 411-416.

5. Дубина Д.А., Ямпольский Л.С., Пуховский Е.С. Использование модифицированных сетей петри при моделировании гибких производственных систем //Автоматизація виробничих процесів.-2001p.2(13).- C.60-67.

6. Интегрированная семантически согласованная среда гиперпространственного моделирования гибких компьютеризированных производственных систем / О.И. Лисовиченко, В.И. Костюк, А.А. Лавров, Л.С. Ямпольский //Автоматизація виробничих процесів.2001p.- 2(13).- C.86-100.

7. Концептуальний підхід до розробки тнтегрованого об'єктноорієнтованого середовища для моделювання ГВС / О.В. Блажко, В.В. Борисюк, А.А. Гілязов, А.С. Птічнікова, О.І. Лісовиченко // Науковий вісник Інституту економіки та нових технологій ім. Ю.І. Кравченка “Нові технології.-Кременчук.- 2003.- Вип.1'(2).- С.81-85.

8. Лавров О.А. Моделювання гнучких дискретно-подійних систем на основі методів з комбінованою симантикою/ Дис. на здоб. наук. ступ. докт. техн. наук, Киӥв. - 2000.- 400 с.

9. Лавров А.А., Лисовиченко О. И., Ямпольский Л. С. Обучение и двухуровневая нечеткая оптимизация в разработке компьютерно-интегрированных систем // Радіоелектроніка, інформатика, управління.- 1999.- 2.- 1999.-С. 114-120. 
10. Лавров О.А., Сігал О.Л., Лісовиченко О.І. Узагальнена композиція сітьових моделей ГВС// Новые решения в современных технологиях. Вестник харьковского государственного политехнического университета.- 1999.- Вып. 58.- с. 32-34.

11. Лісовиченко O.I., Ямпольський Л.С. Семантично-узгоджене середовище гиперпросторових моделей складальних комп'ютерноінтегрованих систем// Адаптивні системи автоматичного управління.- 2000-Вип. 3'(23).- С.137-147.

12. Мейсон Ву, Том Девис, Джеки Нейдер, Дейв Шрайнер OpenGL. Официальное руководство программиста / OpenGL. Prog ramming Guide.Изд-во: ДиаСофт. ISBN 5-93772-041-5.- 2002. - 592 с.

13. Моделювання процесів взаємодії компонентів комп'ютерноінтегрованих систем із застосуванням апарату процесних алгебр / О.В. Блажко, О.І. Лісовиченко, С.С. Пуховський, Л.С. Ямпольський // Адаптивні системи автоматичного управління.- 2003.- Вип. 5'(25).С. 9-28.

14. Моделювання розподіленого управління перепускними спроможностями циклічних виробничих систем / З.А. Банашак, О.І. Лісовиченко, Д.І. Гергі , Л.С. Ямпольський // труды фрилиала мгту им. Н.Э. Баумана в г. Калуге. Специальный выпуск: Материалы международн. науч.-техн. конфр. “Приборостроение-2001”.- С. 158-163.

15. Модифікація апарату сіток петрі і моделювання складних комп'ютерно-інтегрованих систем з іерархічною семантикою подання процесів / П.В. Кузьмін, О.А. Лавров, О.І. Лісовиченко, К.Б. Остапченко, Л.С. Ямпольський // Вісник Житомирського інженернотехнологічного інституту/, Житомир:ЖITI.- 1998. 8.-С. 80-92.

16. Нові підходи до моделювання і управління в гнучких комп'ютеризованих системах / П.В. Кузьмін, О.А. Лавров, К.Б. Остапченко, 3.А. Банашак, Л.С.Ямпольський // Адаптивні системи автоматичного управління.- 1998.-Вип. 1 (21).- С. 47-63.

17. Попов Е.П., Верещагин А.Ф., Зенкевич С.Л. Манипуляционные роботы: динамика и алгоритмы., - М.: Наука.- 1978. - 400 с.

18. Птічнікова А.С., Лісовиченко О.І., Ямпольський Л. С. Дослідження нештатних ситуацій у гнучких комп'ютеризованих виробничих системах з агрегатними станами // Житомир: ЖІТУ.- 2003.- 3(27).C.173-183.

19. Реалізація концепції розподіленого керування з самосинхронізацією потоків транспортних засобів ГВС / З.А. Банашак, О.І. Лісовиченко, Г.М. Ткач, Л.С. Ямпольський // Адаптивні системи автоматичного управління.- 2001.- Вип. 4'(24).- С.88-108.

20. Семантическое согласование описания процессов гибких производственных систем при композиционном моделировании / Леонид Ямпольский, Александр Лавров, Денис Дубина, Олег Лисовиченко, Вадим Швачко // TECHNIKA I TECHNOLOGIA MONTAÏU MASZYN 
IV Mikdzynarodowa Konferencja Naukowo-Technizna 22-25.05.2001 r. Pzeszów - Bystre Specjalny Dodatec do Kwartalnika NaukowoTechnicznego TECHNOLOGIA I AUTOMATYZACJA MONTAÏU.- 2(32).2001.- pp. 61-65.

21. Создание комплексно-интегрированных сред для идентификации и верификации гибких компьютеризованных сборочных систем / Б.Б, Самотокин, Д.И. Герги, А.А. Лавров, К.Б. Остапченко, М.М. Ткач, Л.C. Ямпольский // TECHNOLOGIA I AUTOMATYZACJA MONTAÏU Ogólnopolski Kwartalnik Naukowo - Techniczny.- 3(33).- lipiec-wrzesiec.2001.- pp. 8-11 (ISSN 1230-7661)

22. Ткач Г.М., Лисовиченко О.И. К логистическому моделированию конфигураций материальных потоков в автоматизированных распределенных транспортных сетях//автоматизация: проблемы, идеи, решения: Материалы междунар. науч.-техн. конф., г. Севастополь.- 20-24 мая 2002г.- Севастополь: Изд-во СевГТУ.- 2002.- С. 110-112.

23. Управление дискретными процессами в ГПС / Л.С. Ямпольский, 3. Банашак, К. Хасегава, Б. Крог, К. Такахаши, А.В. Борусан. - К.: Тэхника; Вроцлав: Изд-во Вроцлав. политехн. ин-та; Токио: Токосё.1992. - $251 \mathrm{c}$.

24. Функціонально-еквівалентні перетворення структурних моделей гнучких виробничих систем // Системні технології. Системне моделювання технологічних процесів.- 1999.- Вип. 6.- С. 84-90.

25. Швачко В.В., Поліщук М.М., Ямпольський Л.С. Програмні засоби подання та візуалізації зображень для технічних установок обробки матеріалів // Вісник ЖITI.- 1999.-Вип. 9.- С. 47-51.

26. Швачко В.В., Поліщук М.М., Ямпольський Л.С. Розробка програмного забезпечення для визначення та вызуалізації положень ланок маніпулятора // Адаптивні системи автоматичного управління.- 1999.Вип. 2 (22).- С. 74-81.

27. Шостак В.Ф. Модели и методы управления сложными технологическими комплексами в нештатных (экстремальных) режимах работы в АСУТП // Автоматика и телемеханика.- 1994.- 10.- С.158-164.

28. Ямпольский Л. С., Калин О. М.. Ткач М. М. Автоматизированные системы технологической подготовки робототехнического производства.— К. : Вища шк.- 1987.-270 с.

29. Ямпольский Л. С., Лавров О.А. Штучний інтелект в плануванні та управлінні виробництвом.-К.:Вища школа.- 1995.-255c.

30. Ямпольский Л.С., Полищук М.Н. Концептуальная иерархическая модель гибкой сборочной системы с агрегатными состояниями //TECHNIKA I TECHNOLOGIA MONTAÏU MASZYN IV Miкdzynarodowa Konferencja Naukowo-Technizna 22-25.05.2001 r. Pzeszów - Bystre Specjalny Dodatec do Kwartalnika NaukowoTechnicznego TECHNOLOGIA I AUTOMATYZACJA MONTAÏU.- 2(32).2001. -pp. 39-44. 
31. Ямпольський Л.С., Поліщук М.М., Ткач М.М. Елементи робототехнічних пристроїв і модулі ГВС. - К.: Вища шк.- 1992. - 431 с.

32. Krogh B.H., Screenivas R.S. Essentially Decission Free Petri Nets for Reak-Time Resource Allocation // The Proceedings of the IEEE International Conference on Robotics and Automation. IEE Computer Society Press.- Washington: DC.- 1987.- pp.1005-1010.

33. Lavrov A., jampolskiy L. Conf iguration Synthesis and Ref inement: an approach to Simulation of Heterogeneous distributed Systems // УСИМ.2000.- 3.- pp. 11-17.

34. Lemmer K., Schnieder E. Modeling and Control of Complex Logistic Systems for Manufacturing // Application and Theory of Petri Nets. K.Jensen (ED).- Berlin: Springer-Verlag.- 1992.- pp.373-378.

35. Yampolsky L.S., Lavrov A.A., Semenchenko V.L. and Kusmin P.V. Intelligent Dynamic Models of Computer-Integ rated Manufacturing Systems // The Proceedings of the 1993 European Simulation Sumposium / Delft.1993.- pp.161-163. 